\title{
On the optimization of the construction of ventilation systems during the construction of metro by underground method
}

\author{
Alexander Vartanov ${ }^{1}$, Irina Markova ${ }^{2,{ }^{*}}$ and Anatoly Fedash ${ }^{2}$ \\ ${ }^{1}$ Institute of Comprehensive Exploitation of Mineral Resources Russian Academy of Sciences \\ (IPKON RAS) 111020, 4, Kryukovsky tupik, Moscow, Russia \\ ${ }^{2}$ Moscow State University of Civil Engineering, Yaroslavskoe shosse, 26, Moscow, 129337, Russia
}

\begin{abstract}
The article discusses optimal versions for placement of ventilation systems for deep-laid underground lines, performed in a closed way, with the removal of the ventilation chamber from the ventilation output and placing it either in the ventilation shaft or in a specially constructed ventilation chamber located near the trunk, which significantly simplifies the design of excavation, and as a result, speed up its construction. To reduce the construction time, it is proposed to perform parallel work on the vent development and the ventilation chamber, including the possible installation of process equipment in parallel with the mining operations during the construction of the metro by the underground method.
\end{abstract}

\section{Introduction}

Under modern conditions, ensuring high rates of design and construction of metro facilities, caused by active development of underground space in Moscow, is an important scientific and technical challenge. This task is not possible without the development and modernization of the system of design of underground facilities using a new system of design solutions that can transform and adapt to any mining and geological conditions.

Currently, the most preferred method of construction of subways is an open method that allows you to quickly, safely and with high quality to perform construction and installation works, however the importance and relevance of saves and underground method, which is optimal for deep in-ground stations in dense urban areas and other situations where the construction of an open way is impossible or not optimal. So, in the practice of the Moscow underground construction, most of the buildings are newly created circle line is being constructed by the closed method.

It is known that in modern practice of construction subways underground main mine workings including an open-line tunnels are highly mechanized tunneling complexes with the use of imported and domestic complexes of mining machines, including a highly mechanized panel Board complexes with clay and gidroperita. This allows you to achieve high penetration rates while ensuring proper safety of mining operations. However, auxiliary

${ }^{\star}$ Corresponding author: markova@mgsu.ru 
mine workings, which also include ventilation workings, often continue to be performed using outdated mining technologies, which is explained, first of all, by the economic ineffectiveness of shield technologies with minor lengths of workings (less than 200 meters). Paradoxical situations arise when the construction of auxiliary workings is comparable in time and cost with the construction of main workings.

At the same time in the auxiliary workings often complex technological equipment is installed that ensures the safety of the operation of the subways. Such mining openings also include ventilation openings in which ventilating installations traditionally are located. That is, the construction is carried out sequentially: first, the construction of the production, and then the installation of equipment. And although modern ventilation systems are distinguished by a high degree of factory readiness, it is important to find the best ways to parallelize the construction of workings and installation of process equipment, including by possible transferring the placement of ventilation systems from the ventilation of mine workings either into the trunk or into a specially constructed ventilation chamber located near the trunk.

\section{Materials and Methods}

Consider a typical design solution for the design of ventilation workings in the Moscow metro. The geological structure of the upper part of the geological section in the city of Moscow at the depths of most of the subway structures located underground (less than 50 meters), is of great diversity and is represented by rocks of the Cenozoic, Mesozoic and Paleozoic ages. Modern and Quaternary sediments are represented by loose soils, technogenic sediments, loamy sediments, silty sand, loam with grout, gravel and crushed stone of sedimentary soils. The Cretaceous sediments are mainly sand, sometimes small silty, Jurassic sediments - clays of solid and semi-solid consistency, including sandy silts with the inclusion of phosphorites. Coal deposits are mainly medium-strength limestones with layers of strong and low-strength rock, with marl and clay interlayers, cryptocrystalline medium-strength limestones, with marl and clay interlayers, and limescale clays.

Hydrological conditions are characterized by the presence of several aquifers bearing both pressure and non-pressure character. The maximum pressure is up to 12.5 meters. Seasonal fluctuations of levels up to 1.5 meters. The peculiarity of the hydrogeological structure of Moscow is the appearance of local aquifers - "upper lines" during periods of hydrogeological maxima. In general, the geological and hydrogeological conditions in the city complicate, but do not hinder the use of the whole complex of methods for conducting mine workings, and using effective design solutions, the absence of design errors, proper organization and proper control of the construction process, allow for high rates of construction of underground structures with ensuring the proper level of its security.

Ventilation systems are installed at stations, dead ends and in each inter-station haul: one - with a haul length of less than 2 kilometers, three or more with a long haul length.A typical solution in the construction of metro is the placement of a specialized mine workings - the ventilation chamber in the main ventilation openings in the immediate vicinity of the ventilated tunnels. With such a layout solution, the main mining and capital workings are: the ventilation shaft (ventilation shaft) - a vertical mine working with access to the surface, with a diameter of 6-8 meters with a design depth, generally up to 50 meters. The production is fixed with precast or monolithic reinforced concrete, and in some cases in difficult geological conditions, and cast iron tubing. Ventilation openings are round or ellipticalsection mine openings with a semi-circular or horseshoe vault, often with a broad base with characteristic clear heights of up to 4 meters and 6 meters of clear maximum horizontal size. In the zones of junction to the trunks, there are often produced square sections with sizes up to 5-6 meters in height and 6 meters in width. Ventilation chambers are located along the 
axis of ventilation generation and have dimensions of up to 7 meters or more horizontally and 6 meters vertically in the light at lengths up to 30 meters. Typical cross-section of the ventilation chamber horseshoe. When excavating, the mine workings are fastened first with temporary and then with permanent lining, mainly monolithic reinforced concrete. In difficult geological conditions, the depreciation space is plugged and / or metal insulation is applied. The designs described are often located in water-saturated, low-bearing rock massifs due to the tradition of auxiliary workings that are widely used in practice, "in the same plane" with the main ones. All of the above features lead to the need to apply special technologies of penetration, including methods of controlling rock pressure, hardening of rocks, methods of reducing water inflows, etc. Separately, it should be noted the presence of large-span and large chambers in the axes of mining. Such chambers are often performed not in full profile, in several stopovers, which ultimately leads to a sharp increase in the construction period and a decrease in the quality and safety of work.

Thus, the question of changing the structures of ventilation workings, using cheaper and more reliable technical solutions, speeding up the time and improving the quality of construction, is now becoming particularly acute. Fundamentally important in this situation is the possibility of considering the removal of ventilation systems from the ventilation output. In this case, the optimal location for the ventilation installation can be either a trunk in its upper part or a specially constructed ventilation chamber located near the trunk at depths of up to 8 meters. This arrangement of the ventilation chamber allows to significantly simplify its design due to its location outside the zone of water-saturated and unstable arrays, which are located mainly at more significant depths. Bringing the ventilation chamber closer to the day surface makes it possible to use in its construction not mining methods, but standard construction equipment, to eliminate laborious and expensive work on stabilization and strengthening of rock massifs. It should be noted that the placement of ventilation systems in the near-barrel spaces near the surface is typical for Russian mining enterprises. The removal of the ventilation chamber from the ventilation workings will significantly simplify the design of the output, and as a result, speed up its construction. Also, the reduction of construction time can be achieved by parallel execution of works on sinking and arrangement of ventilation workings and ventilation chamber, including the possible installation of process equipment in parallel with the implementation of mining operations. Summarizing the above, we can speak about the transformation of the closed method of building the ventilation systems of metros into combined ones - with the inclusion of elements of the open method (Table 1).

Separately, it should be noted that the removal of a large-sized ventilation chamber into the near-bottom space is a way to protect the surrounding buildings from the negative impact of mining, including by reducing the size of the zone of influence of the structure due to a decrease in the diameter of the mine workings, reducing the depth of the chamber and increasing the distance from cameras up to the main facilities. The main parameters used in the mathematical formulation of the optimization problem for the construction of the ventilation systems of metros are given in Table 2.

The spatial position of the ventilation workout after the removal of the ventilation chamber from it is chosen taking into account the minimization of the cost of mining operations, including minimizing the length of the possible location of its perpendicular to the distillation tunnels / tunnel, as well as placing it in strong, stable and low-watered rocks, which will significantly reduce its construction time and cost. It is possible to carry out ventilation workings using both shield shield methods and mining methods, including special methods for improving the engineering and technological properties of the massif with meeting the conditions for ensuring the safety of surrounding structures by performing a set of technological, geotechnological and structural measures, primarily reducing the size of the 
loose wellbore space, swabbing upstream space quick-hardening mixtures, fixing $\mathrm{s}$ on the track penetration.

Table 1. Main technological processes and types of work during ventilation openings

\begin{tabular}{|c|c|c|c|c|}
\hline $\begin{array}{l}\text { Process, type of } \\
\text { work }\end{array}$ & $\begin{array}{l}\text { Excavation of } \\
\text { the trunk }\end{array}$ & $\begin{array}{l}\text { Holding the } \\
\text { ventilation } \\
\text { working }\end{array}$ & $\begin{array}{l}\text { Construction of the } \\
\text { ventilation chamber } \\
\text { in the tunnel space }\end{array}$ & $\begin{array}{l}\text { Construction of } \\
\text { the ventilation } \\
\text { chamber in the } \\
\text { near-ceiling } \\
\text { space }\end{array}$ \\
\hline Method & $\begin{array}{l}\text { Closed } \\
\text { (underground) }\end{array}$ & $\begin{array}{l}\text { Closed } \\
\text { (underground) }\end{array}$ & $\begin{array}{l}\text { Closed } \\
\text { (underground) }\end{array}$ & Open \\
\hline Technology & $\begin{array}{l}\text { Shaft sinking } \\
\text { complex }\end{array}$ & $\begin{array}{l}\text { Shield method, } \\
\text { Mining }\end{array}$ & Mining & Trench \\
\hline $\begin{array}{l}\text { Destruction } \\
\text { array }\end{array}$ & Mechanical & $\begin{array}{l}\text { Mechanical, } \\
\text { drilling and } \\
\text { blasting }\end{array}$ & $\begin{array}{l}\text { Mechanical, } \\
\text { drilling and } \\
\text { blasting }\end{array}$ & Mechanical \\
\hline $\begin{array}{l}\text { Moving broken } \\
\text { rock mass }\end{array}$ & $\begin{array}{l}\text { Clamshell, } \\
\text { bucket }\end{array}$ & $\begin{array}{l}\text { Self-propelled } \\
\text { machinery, } \\
\text { conveyor } \\
\text { systems }\end{array}$ & $\begin{array}{l}\text { Self-propelled } \\
\text { machinery, } \\
\text { conveyor systems }\end{array}$ & Motor transport \\
\hline False timbering & Tightening & $\begin{array}{l}\text { Frames, } \\
\text { anchor systems }\end{array}$ & $\begin{array}{l}\text { Frames, } \\
\text { anchor systems }\end{array}$ & $\begin{array}{l}\text { Tongue, } \\
\text { sheeting wall }\end{array}$ \\
\hline $\begin{array}{l}\text { Permanent } \\
\text { shore }\end{array}$ & $\begin{array}{l}\text { Monolithic } \\
\text { reinforced } \\
\text { concrete, precast } \\
\text { concrete, cast } \\
\text { iron tubing }\end{array}$ & $\begin{array}{l}\text { Monolithic } \\
\text { reinforced } \\
\text { concrete, } \\
\text { precast } \\
\text { concrete, cast } \\
\text { iron tubing }\end{array}$ & $\begin{array}{l}\text { Monolithic } \\
\text { reinforced } \\
\text { concrete, precast } \\
\text { concrete, cast iron } \\
\text { tubing }\end{array}$ & $\begin{array}{l}\text { Monolithic } \\
\text { reinforced } \\
\text { concrete }\end{array}$ \\
\hline $\begin{array}{l}\text { Managing the } \\
\text { status of } \\
\text { overworking } \\
\text { spaces }\end{array}$ & $\begin{array}{l}\text { Tamponage } \\
\text { quick-hardening } \\
\text { solutions }\end{array}$ & $\begin{array}{l}\text { Tamponage } \\
\text { quick- } \\
\text { hardening } \\
\text { solutions }\end{array}$ & $\begin{array}{l}\text { Tamponage } \\
\text { quick-hardening } \\
\text { solutions }\end{array}$ & $\begin{array}{l}\text { Backfilling by } \\
\text { seal }\end{array}$ \\
\hline $\begin{array}{l}\text { Manage the } \\
\text { state of the } \\
\text { array on the } \\
\text { road excavation }\end{array}$ & $\begin{array}{l}\text { Cementation by } \\
\text { sanding and } \\
\text { injection } \\
\text { methods with } \\
\text { quick-hardening } \\
\text { solutions }\end{array}$ & $\begin{array}{l}\text { Cementation } \\
\text { by sanding and } \\
\text { injection } \\
\text { methods with } \\
\text { quick- } \\
\text { hardening } \\
\text { solutions } \\
\end{array}$ & $\begin{array}{l}\text { Cementation by } \\
\text { sanding and } \\
\text { injection methods } \\
\text { with quick- } \\
\text { hardening } \\
\text { solutions }\end{array}$ & $\begin{array}{l}\text { In most cases not } \\
\text { required }\end{array}$ \\
\hline $\begin{array}{l}\text { Control and } \\
\text { monitoring }\end{array}$ & $\begin{array}{l}\text { Surveying- } \\
\text { geodetic control } \\
\text { Geophysical } \\
\text { monitoring } \\
\text { Severability } \\
\text { spaces } \\
\text { Quality control } \\
\text { of grouting }\end{array}$ & $\begin{array}{l}\text { Surveying- } \\
\text { geodetic } \\
\text { control } \\
\text { Geophysical } \\
\text { monitoring } \\
\text { Severability } \\
\text { spaces } \\
\text { Quality control } \\
\text { of grouting } \\
\end{array}$ & $\begin{array}{l}\text { Surveying- } \\
\text { geodetic control } \\
\text { Geophysical } \\
\text { monitoring } \\
\text { Severability } \\
\text { spaces } \\
\text { Quality control of } \\
\text { grouting }\end{array}$ & $\begin{array}{l}\text { Surveying- } \\
\text { geodetic control }\end{array}$ \\
\hline
\end{tabular}

It is rational to carry out preliminary reinforcement of the massif using the method of boron-mixing cementation (in the variant of jet cementation). Cementation is subject to rocks in the contour of development and at a distance of at least $1 / 2$ of the maximum size of excavation outside its contour. The distance between the technological wells is used in accordance with the parameters of the equipment used, taking into account the fact that this distance should not exceed 0.7 of the expected diameter of the emerging rock-cement string. 
Cementation is advisable to perform quick-hardening mixtures. Brand mix is set by the project. In the locks of the resulting rock-cement massif injection grouting is performed. Injection grouting is also performed with quick-hardening mixtures or polymer compositions in accordance with the established project. The work on the strengthening of the array is optimally performed in one step. The contours of the workings from which drilling operations are carried out are further strengthened.

To ensure the safety of work by mining methods, a screen is formed of steel pipes with a diameter of at least $150 \mathrm{~mm}$ outside the contour of the mine and filled them with cement mortar. It is advisable to design mining methods using mining methods, taking into account the presence of highly efficient self-propelled excavation and loading equipment, using small-scale mechanization and minimizing manual labor. In some cases, the project may justify the use of drilling and blasting methods, while ensuring the sustainability of mine workings and goaf and minimizing the seismic impact on the surrounding mine workings and structures. When excavating mine workings, temporary fastening is necessarily erected, the most frequently used anchor systems are with tightening and strengthening of the goaf, as well as frame lining. Temporary fixing of the ongoing mine work should be provided for by the project. Permanent lining - monolithic reinforced concrete.

The process of the mine workings must be accompanied by geotechnical control and monitoring. Technologically changeable rock massifs, as well as structural elements of mine workings interacting with massifs, are subject to control. The main purposes and objectives of control are: the study of the geological structure of rock massifs and the hydrodynamic regimes of underground and surface waters in a natural and man-made state, the geological environment under and around buildings, changes in the massif under technogenic impact; study of the stress-strain state of rock massifs in the natural and man-made altered state under buildings and around underground structures, monitoring changes in the stress-strain state of the massif under man-made impact. Control of gas manifestations and emanations; forecasting of dangerous hydrogeological and geodynamic phenomena; prediction of possible destruction of structures, buildings and structures under the influence of the natural and man-made geological environment.

Table 2. The main characteristic parameters for the mathematical formulation of the optimization problem

\begin{tabular}{|c|c|c|}
\hline $\begin{array}{c}\text { Optimization } \\
\text { task }\end{array}$ & Subtasks & Processes and methods \\
\hline $\begin{array}{l}\text { Safety } \\
\text { enhancement } \\
\text { construction } \\
\text { work }\end{array}$ & $\begin{array}{l}\text { Reducing the amount } \\
\text { of work performed in a } \\
\text { closed way. } \\
\text { The use of highly } \\
\text { effective } \\
\text { geotechnologies. } \\
\text { Reducing the risk of } \\
\text { occurrence of } \\
\text { dangerous natural and } \\
\text { anthropogenic } \\
\text { manifestations during } \\
\text { mining operations. }\end{array}$ & $\begin{array}{l}\text { Preferential conduction of mine workings by shield method with the } \\
\text { combination of the processes of penetration and fastening in a single } \\
\text { technological cycle. } \\
\text { Reduction of mining operations by mining, implementation of the } \\
\text { method using self-propelled machinery, minimization of the } \\
\text { volume of blasting operations. } \\
\text { Temporary fixing of mine workings with anchor systems, reducing } \\
\text { the use of frame support. } \\
\text { Permanent fastening of mine workings monolithic or precast } \\
\text { concrete. } \\
\text { Improving the stability and carrying capacity of rock mass using } \\
\text { highly efficient methods of consolidation and cementation. } \\
\text { Reduction of water inflows in the mine workings. }\end{array}$ \\
\hline $\begin{array}{l}\text { Reduced } \\
\text { construction } \\
\text { time }\end{array}$ & $\begin{array}{l}\text { Reducing the amount } \\
\text { of work performed in a } \\
\text { closed way. } \\
\text { Increase the amount of } \\
\text { work performed by the } \\
\text { open method. } \\
\text { Increase the amount of } \\
\text { work performed in } \\
\text { parallel. }\end{array}$ & $\begin{array}{l}\text { Reducing the volume of mining operations, including: breaking } \\
\text { down and loading of rock mass, transport of rock mass through } \\
\text { underground workings, delivery of rock mass to the surface, } \\
\text { temporary mounting of mine workings, permanent mounting of } \\
\text { mine workings, hardening of rock massifs, drainage and ventilation } \\
\text { of underground mine workings } \\
\text { Increased scope of work: fastening open mines by efficient } \\
\text { methods, including sheet piling and / or walls in the ground, }\end{array}$ \\
\hline
\end{tabular}




\begin{tabular}{|c|c|c|}
\hline & & $\begin{array}{l}\text { development of pits with highly efficient loading and transport } \\
\text { complexes } \\
\text { The combination of open and underground mining in a single } \\
\text { technological cycle. }\end{array}$ \\
\hline $\begin{array}{l}\text { Reducing the } \\
\text { cost of } \\
\text { construction } \\
\text { and } \\
\text { installation } \\
\text { works. }\end{array}$ & $\begin{array}{l}\text { Reducing the amount } \\
\text { of work performed in a } \\
\text { closed way. } \\
\text { Increase the amount of } \\
\text { work performed by the } \\
\text { open method. }\end{array}$ & $\begin{array}{l}\text { Reducing mining volumes, including: Breaking down and loading } \\
\text { of rock mass, transporting rock mass through underground } \\
\text { workings, discharging rock mass to the surface, temporary } \\
\text { mounting of mine workings, permanent mounting of mine } \\
\text { workings, hardening rock massifs, drainage and ventilation of } \\
\text { underground mine workings. } \\
\text { Increased scope of work: Fastening open mines by efficient } \\
\text { methods, including sheet piling and / or walls in the ground, } \\
\text { development of pits with highly efficient loading and transport } \\
\text { complexes. }\end{array}$ \\
\hline $\begin{array}{l}\text { Reducing the } \\
\text { negative } \\
\text { impact on the } \\
\text { environment }\end{array}$ & $\begin{array}{l}\text { Reducing } \\
\text { displacement and } \\
\text { deformations in the } \\
\text { array. } \\
\text { Decrease in } \\
\text { subsidence of the day } \\
\text { surface. } \\
\text { Formation effectively } \\
\text { of a system for } \\
\text { monitoring and } \\
\text { managing the state of } \\
\text { rock massifs in natural } \\
\text { and anthropogenically } \\
\text { altered forms. }\end{array}$ & $\begin{array}{l}\text { Reducing the diameters of mine workings. } \\
\text { The use of shield methods of mining instead of mining. } \\
\text { High speed of penetration and fastening of mine workings. } \\
\text { The use of technologies excluding the presence of loose space in } \\
\text { the process of penetration. } \\
\text { Tamponage of the packing spaces with cement and alumina-cement } \\
\text { solutions. } \\
\text { Cementation of arrays on the route of making. } \\
\text { Strengthening the overlying rock massifs. } \\
\text { Effective trace mining. Placement of workings in stable and low- } \\
\text { watered rocks. } \\
\text { Organization of technological control of the implementation of } \\
\text { geotechnologies and interaction of structures and arrays, control of } \\
\text { displacements and deformations of rock masses; } \\
\text { organization of surveying and geodetic monitoring of surface } \\
\text { conditions. }\end{array}$ \\
\hline
\end{tabular}

Technological quality control of cementation performance - control hydrotesting/injection, as well as on the study of water inflow into the control wells. It is also recommended to perform video logging of control wells. It is also advisable to produce ultrasound scanning between control wells.

The slope of the ventilation output for the organization of drainage should be arranged in the direction of the barrel with the construction of a closed type in the sump of the barrel, which will ensure the normal functioning of the drainage both in winter and in summer in any direction of the air flow.

\section{Results}

NRU MGSU [14] and IPKON RAS [1 - 13] for many years carry out research activities and scientific and methodological support of the design process of mining in underground city construction. A large array of statistical data has been developed which allows conclusions to be drawn about the optimal spatial distribution of mine workings, methods of mine workings in difficult mining and geological conditions of the urban environment.

Carrying out optimization of the design of ventilation systems during the construction of the underground by the underground method allows minimizing the time and cost of construction by reducing the diameters and length of mine workings, and as a result reducing their zone of influence. The removal of large-sized structures closer to the surface allows to reduce construction costs by reducing material costs, applying progressive open methods of construction, reducing the zone of influence of structures.

The use of shield methods and minimization of the mining method in combination with special methods for improving the engineering and technological properties of rock massifs - chemical fixing and cementation of massifs along the roadway, plugging out the working spaces, protects the surrounding building from the negative impact of mining operations. 


\section{Conclusions}

The presented options for optimizing the design of ventilation systems during the construction of the metro by underground method can significantly reduce the period of construction of underground mine workings. When changing the spatial position of the ventilation chamber and placement of ventilation openings perpendicular to the tunnel significantly reduces the construction time and its cost. It is recommended to use special methods to improve the engineering and technological properties of the array when conducting ventilation openings. For sinking, it is proposed to use shield methods and mining methods, self-propelled machinery and means of small-scale mechanization, optimization of the technological mode of sinking with the earliest construction of temporary supports.

\section{References}

1. A.D. Ruban Proceedings of the scientific symposium "Miner's Week 2009. 33 (2009).

2. A.D. Ruban, A.Z. Vartanov, I.V. Kovpak. Mining J. 22 (2010)

3. A.Z.Vartanov, A.D. Ruban, V.L. Shkuratnik, Methods and instruments for environmental monitoring and environmental monitoring (Mining Book, 2009)

4. V.S. Yamshchikov, Methods and means of research and control of rocks and processes (Nedra, 1982)

5. N.K. Kapustyan, V.K.Tarakanovsky, A.B. Voznyuk, A.N. Klimov. Sat. scientific papers. 192 (2010)

6. V.N. Zakharov, A.Z.Vartanov, O.N. Malinnikova, I.V.Petrov, A.V. Fedash, R.A. Akhmedgaliev Research, monitoring and control of the structure and properties of subsoil megalopolises and zones of urban industrial agglomerations. Part I. General rules of work: Guidelines ( IPKON RAS, 2015)

7. V.N. Zakharov, A.Z.Vartanov, O.N. Malinnikova, I.V.Petrov, A.V. Fedash, E.V. Fedorov. Part II. (IPKON RAS, 2016)

8. A. Z. Vartanov, A.A. Kobyakov A.A., S.M. Romanov, I.V.Petrov, A.V. Fedash. M. I. A. J. (S.T.J.) 284 (2015)

9. A.Z. Vartanov, A.V. Fedash, I.V.Petrov. M. I. A. J. (S.T.J.) 65 (2015)

10. S.D. Viktorov S.D., A.N. Kochanov. Bulletin RAS Physics 74 (2015)

11. K.N. Trubetskoy, M.A. Iofis, E.N. Esina. Journal of Mining Sciences 54 (2015)

12. G.V. Kalabin. Environmental pollution and protection 31 (2016)

13. D.L. EremenkoV.A., D. L. Neguritsa. Eurasian Mining 24 (2016)

14. M. G. Zertsalov, A. D. Potapov, A. V. Man'ko. Soil Mechanics and Foundation Engineering 201 (2008)

A. Haak. Tinnels\& Tunnelling 36 (2002)

15. D. Nicholson D. Geotehnet 74 (2005)

16. W.W. Ng Charles, H.W. Huang, G.B. Liu. IS-Shanghai 886 (2008)

17. C. D. F. Rogers, H. Parker, R. Sterling, X. Shi, J.-P. Godard, H. Admiraal, T. Hanamura, I. Vähäaho, N. Bobylev Urban Design and Planning 78 (2012)

18. H. Chakeri, A. Talebinejad, M. Moosavi, B. Ünver Soil Mechanics and Foundation Engineering 132 (2012)

19. S. O. Zege, I. I. Broid Soil Mechanics and Foundation Engineering 230 (2011) 